4. Badran Z, Gaudin A, Struillou X, Amador G, Soueidan A. Periodontal pockets: A potential reservoir for SARS-CoV-2? Med Hypotheses. 2020. №143. P.109907.

5. Miller CS. Viruses: are they really culprits for periodontal disease? A critical review. J Investig Clin Dent. 2014. №5(3). P.243.

6. Ansari R, Gheitani M, Heidari F, Heidari F. Oral cavity lesions as a manifestation of the novel virus (COVID-19). Oral Dis. 2021. № 3. P.771-772.

7. Dufty J, Gkranias N, Donos N. Necrotising Ulcerative Gingivitis: A Literature Review. Oral Health Prev Dent. 2017. №15(4). P.321-327.

8. Grando LJ, Yurgel LS, Machado DC, Silva CL, Menezes M, Picolli C. Manifestações estomatológicas, contagem de linfócitos T-CD4+ e carga viral de crianças brasileiras e norte-americanas infectadas pelo HIV [Oral manifestations, CD4+ T-lymphocytes count and viral load in Brazilian and North-American HIV-infected children]. Pesqui Odontol Bras. 2002. № 16(1).P. 18-25.

DOI https://doi.org/10.30525/978-9934-26-113-8-13

\title{
THE STATISTIC INVESTIGATION ON APPROACHES IN SELECTION DIFFERENT DIAGNOSTIC METHODS IN THE TREATMENT OF PATIENTS WITH GENERALIZED PERIODONTITIS USED BY DENTISTS. RESULTS OF ANONYMOUS QUESTIONNAIRES
}

\author{
Symonenko R. V. \\ Candidate of Medical Science, \\ Assistant at the Department of Prosthodontic Dentistry \\ Bogomolets National Medical University \\ Kofanov V. O. \\ Student \\ Bogomolets National Medical University \\ Kyiv, Ukraine
}

One of the most widespread diseases after caries are periodontal diseases, according to the WHO [1, s.14]. Still, generalized periodontitis relates to diseases that have the least successful treatment efficacy. The lack of a clear understanding of the causality of the periodontal disease progression 
significantly decreases the ability for treatment and prevention. Despite a large number of scientific developments, the rehabilitation of patients with generalized periodontitis remains a relevant and unsolved problem [4, s. 2]. The modern treatment concept for patients with generalized periodontitis includes applying holistic examination and planning the incremental treatment involving therapeutic, surgical, orthodontic, and prosthodontic methods. These are essentials for achieving maximal and fast regaining the masticatory system `s function. Taking those factors into consideration, it may be assumed, that diagnostic methods selection along with planning the sequence of treatment may become a determining factor for achieving prognosed and positive results along with avoiding complications [5, s. 15] [7, s. 12] $[9$, s. 3]. Therefore, the field of investigation on personalized methodlogical approaches for the examination of patients with periodontal diseases requires squeamish attention from scientists and dentists regarding its extreme relevance.

Purpose: The purpose of the study is to analyze what diagnostic methods are given preference by dentists with different specializations in the treatment for patients with generalized periodontitis according to commonly agreed protocols and clinical cases through anonymous questionnaires.

Methods: Anonymous questionnaires were sent to 448 dentists from Kyiv, Kharkiv, Odesa, and Dnipro on dental clinics` emails as well as in hard-copy format. All dental clinics, involved in the questionnaire, don 't have spatialized periodontists. Every dentist has a specialty in one of the following prosthodontic, therapeutic, orthodontic, and GP dentistry. The questionnaire consists of 21 questions, 12 of which relate to diagnostic methods of periodontal diseases. Dentists were asked to answer the following question, main of them:

- How often do you meet patients with generalized periodontitis in your practice?

- What protocol of examination do you prefer?

- What diagnostic methods in the treatment of periodontal diseases do you prefer in your everyday practice?

- What classification of periodontal diseases do you use in your everyday practice?

- Does your choice of examination protocol for patients with periodontal diseases depends on a certain clinical case?

- Do you support the concept of minimally invasive dentistry and how does it exemplify in your practice?

- What methods and tools do you apply to increase motivation in patients with generalized periodontitis for achieving more detailed assessment and accurate treatment?

We also analyzed the age and work experience of each dentist. 
Statistical processing and analysis of data were conducted using packages of application programs StatSoft Statistica 9.0 Microsoft Excel 2010.

Results: In a survey of 448 dentists, $38,3 \%$ of interviewees make their choice of the diagnostic method depending on a certain clinical case, 69\% take an X-ray in the form of orthopantomography, 4,5\% of interviewee use index assessment of periodontal status, $13 \%$ of dentists take the CT. Only $6 \%$ of interviewees can conduct myography in the process of diagnostics; $9,7 \%$ of interviewees conduct qualifying and quantifying valuation of occlusion; $1,2 \%$ - conduct temporary teeth splinting for diagnostics. It was obtained through the survey, that $61 \%$ of interviewees are correctly informed about the technique of using the T-scan system, 58\% - computer video system, and $22 \%$ - the digital occlusal analysis. Thus, $59 \%$ of dentists don't know the difference in valuation of the information received from different methods of occlusion assessment. Also $61 \%$ - try to involve the minimally invasive dentistry, so-called conservative protocol, in their everyday practice, but only $29 \%$ of interviewees involve motivational component for full and accurate diagnostic. Analyzing the age of interviewees, who gives preference to the differential systematic approach in diagnostic, which depends on a certain clinical case, it was obtained that $51 \%$ of dentists were $35-44$ years of age, $24 \%$ - from 25 to 34 years of age, $18 \%$ - from 45 to 54 years old, and only $7 \%$ of dentists were over 55 years of age.

Conclusions: Despite widespread of this pathology, a large percentage of prosthodontists use only commonly agreed clinical and radiographical methods of examination, that is, measuring teeth mobility grade, conventional methods of occlusion valuation, and orthopantomography. Neither conduction of accurate occlusion and articulation analysis, including computerized analysis, nor depth of periodontal pockets analysis used by prosthodontists. They don't use the index assessment of periodontal status at all. The dentists don't analyze the sensitivity level of vital teeth, considering the abovementioned manipulations time-consuming and impractical. Also, a large number of dentists refers to a lack of motivation in patients regarding longterm prospects for the course of the disease and vagueness of long-term prognosis. Thus, most dentists don't use the holistic approach to treatment for the disease, trying to personalize it. This demonstrates the decreased awareness and, in a way, the bias for conservative treatment methods. The decreased percentage of specialists, who involve motivational tools in their everyday practice demonstrates a lack of interest in long-term cooperation with the patient and potential responsibility for prognosing the course and results. Regarding the WHO recommendations on the concentration of effort on increasing public motivation to prevent dental diseases, domestic specialized publications need to pay extra attention to differential approach in diagnostic methods`selection depending on a certain clinical case. 
July 9-10, 2021

\section{References:}

1. Oral health worldwide. A report of FDI World Dental Federation. 2015. S. 14

2. Petersen PE, Bourgeois D, Ogawa H, Estupinan-Day S, Ndiaye C. The global burden of oral diseases and risks to oral health.Bull World Health Organ. 2005;83(9):661-669.

3. Global oral health data bank. Geneva: World Health Organization; 2004.

4. Petersen PE, Ogawa H. Strengthening the prevention of periodontal disease - the approach of WHO. Geneva: World Health Organization, Global Oral Health Programme; 2005. S. 2

5.Маскурова Ю. В. Повышение эффективности комплексного лечения больных с хроническим генерализированным пародонтитом на фоне постоянного стресса. Дисс. кан. мед. наук, - 2018. № 135. С. 15.

6.Копчак О. В. Розповсюдженість і клінічні особливості перебігу гіперестезій дентину при захворюваннях пародонту. Соврем. Стоматология. 2013; 5(69): 22-26.

7.Арсенина О.И, Попова А.В., Гус Л.А. Значение окклюзионных нарушений при дисфункции нижнечелюстного сустава. Стоматология 2014; 93(6): 64-67. С. 12.

8. Чопчик В.Д. Задоволеність пацієнтів стоматологічною допомогою у стоматологічному центрі. «Медична наука та практика в умовах сучасних трансформаційних процесів» : зб. тез наукових робіт учасників міжнар. наук.-практ. конф., (м. Львів, 26-27 квітня 2019 р.). Львів, 2019. C. 62-66.

9. Симоненко Р. В. Эффективность применения Admira Protect (VOCO) для устранения гиперэстезии зубов, как манифестированного шага координированных вмешательств в процессе реабилитации пациентов с генерализированными болезнями пародонта. Сучасна стоматологія. 2020; 1(100): 115-120. С. 3.

10. Симоненко P. В. Применение пасты «Remin Pro» (VOCO) при лечении гиперестезии эмали твердых тканей зубов (клиникоэкспериментальное исследование) / Р. В. Симоненко // Современная стоматология. - 2016. - № 3. - С. 7-11.

11. Sutter, Ben. Digital Occlusion Analyzers: A Product Review of T-Scan 10 and Occlusense. 2019;2. 2-31

12. Kerstein, Robert. Current Applications of Computerized Occlusal Analysis in Dental Medicine. General dentistry. 2001;49. 521-30. 